\title{
Chromium-Induced Hepatotoxicity and Potential Protective Effect of Selenium in Adult Male Albino Rat: A Histological, Immuno-Histochemical and Molecular Study
}

\author{
AZZA I. FARAG, M.D. and EMAN S. EL-SHETRY, M.D. \\ The Department of Human Anatomy and Embryology, Faculty of Medicine, Zagazig University, Egypt
}

\begin{abstract}
Background: Chromium $(\mathrm{Cr})$ is a main environmental contaminant, famous for its major poisonous effects. Cr (VI) induces variable health hazards. Selenium (Se) is a micronutrient with anti-oxidant activity.

Aim of Study: This study aims to demonstrate the protecting role of selenium in chromium-induced hepatotoxicity in adult male albino rat.

Material and Method: Thirty six adult healthy male albino rats 3-6 months of age were divided into four groups $(9$ animals for each): Group I (control): Fed on balanced diet and water; group II (Se-group): Received daily dose of sodium selenite $(0.25 \mathrm{mg} / \mathrm{kg} \mathrm{B.W}$, dissolved in distilled water); group III (Cr-treated): Received daily dose of potassium dichromate (700ppm equivalent to $67 \mathrm{mg} / \mathrm{kg} \mathrm{B.W}$, in distilled water); group IV; received potassium dichromate in combination with sodium selenite (as mentioned in groups II \& III respectively). Blood samples were drawn from tail vein for biochemical examinations, and after sacrifice fresh liver specimens were collected for histological, immunohistochemical studies and real-time RT-PCR analysis of oxidative stress genes.
\end{abstract}

Results: Chromium motivated oxidative stress process, through producing significant down regulation of the gene expression levels of the anti-oxidant genes (CAT, SOD1 and $\mathrm{GPx}$ ) as compared to control rats, thus inducing different hepatic histopathological changes in the form of loss of the normal arrangement of hepatocytes with dilated central vein. Dilated congested portal vein with thick wall and mononuclear cellular infiltrations were noticed. In addition, fatty degeneration, vacuolization and degeneration of hepatocytes were observed. Moreover, bile ducts showed proliferation and stratifications of their epithelial lining and some sinusoids showed slight dilatation. These histopathological changes were associated with high statistical significant increase in serum level of (ALT, AST and total bilirubin) in group III (Cr -treated) as compared with groups (I and II). Se co - administration with $\mathrm{Cr}$ in group IV showed less histopathological disturbances and induced a statistical significant decrease in serum level of (ALT, AST and total bilirubin) as compared with group III (Cr-treated). Such changes may be attributed to up regulation of gene expression levels of anti-oxidants

Correspondence to: Dr. Azza Ismael Farag,

E-Mail: azza ismael@ hotmail. com. genes (CAT, SOD1 and GPx) under influence of Se. in comparison to group III ( $\mathrm{Cr}$-treated).

Conclusion: Chromium-induced oxidative stress, biochemical, histopathological and immunohistochemical hepatic disturbances which were less manifested by co-administration of selenium.

Key Words: Heavy metals - Chromium - Oxidative stress Selenium-Liver.

\section{Introduction}

CHROMIUM $(\mathrm{Cr})$ is a natural heavy metal, found in different forms. The trivalent $\mathrm{Cr}$ (III) and hexavalent $\mathrm{Cr}(\mathrm{VI})$ are considered the most common forms [1]. Potassium dichromate (K2Cr2O7) is one of the hexavalent chromium compounds, commonly found in brownfields, public distribution water systems, surface and subterranean waters throughout the industrialized world. The extensive use of $\mathrm{Cr}$ (VI) to produce stainless steel, leather industry, leads to its widespread distribution in the environment, in addition to work-related exposure of millions of workers all over the world [2,3].

Several health risks may occur due to exposure to $\mathrm{Cr}(\mathrm{VI})$ as increased risk of lung cancer, asthma, cancer prostate, skin ulcerations, psychoneurotic

\footnotetext{
Abbreviations:

$\mathrm{Cr}(\mathrm{VI}))$ : Chromium.

$\mathrm{Se} \quad$ : Selenium.

SOD : Superoxide dismutase.

CAT : Catalase.

GPx : Glutathione peroxidase.

AST : Aspartate aminotransferase.

ALT : Alanine aminotransferase.

ALB : Albumin.

HSCs : Hepatic Stellate Cells.

GFAP : Glial Fibrillary Acidic Protein expression.

H\&E : Haematoxylin \& Eosin.
} 
and behaviour changes [4]. In addition, extensive tissue damage occurs to the animals exposed to $\mathrm{Cr}$ (VI), as lesions of the testis, spleen, kidney and liver. The hepatic affection is of great importance due to the essential role of the liver in converting the environmental xenobiotics $[\mathbf{5 , 6 ]}$.

Hepatic Stellate Cells (HSCs) occupy the peri sinusoidal space (of Disse) play a major role in the hepatic fibrosis process. The activity of these cells increase with increased hepatic fibrogenesis $\&$ necro-inflammatory activity $[7,8]$

Fibrosis of the liver tissue is a wound restorative process that causes structural changes in the liver tissue and its clinical manifestations may not be apparent until late stages $[\mathbf{9 , 1 0 ]}$.

Glial fibrillary acidic protein (GFAP) is a protein filament which is present in glial cells and recently, it is considered an early indicator of HSCs stimulation in hepatitis, as its expression precedes fibrous tissue formation [11]

Selenium (Se) is an important micronutrient, that plays a major role as antioxidant for detoxification of heavy metals. Moreover, it keeps the lipid components of the cell membrane from harmful effects of reactive oxygen species (ROS) produced due to oxidative stress process. So that, it plays an important role in maintaining cell membrane structure and subsequently all cell functions [12,13]

According to our knowledge, there are insufficient studies on the chromium hepatotoxicity as regard the structural, functional and molecular changes. So that this study illustrated the biochemical, m.RNA expression levels changes of oxidative stress-related genes, histopathological and immunohistochemical effects of $\mathrm{Cr}$ on adult male rat's liver in addition to the hepatoprotective role of Se.

\section{Patients and Methods}

\section{1- Chemicals:}

a- Potassium dichromate:

It is common inorganic odourless, bright red orange water soluble crystalline powder and was purchased from (El-Gomhoria Company for Chemical and Medical Trading, Zagazig, Egypt).

$b$ - Sodium selenite:

It is an odourless, whitish and water soluble powder obtained from (Sigma-Aldrich Chemical Company).

\section{2- Experimental animals and design:}

The current study was carried out from March 2019 to October 2019 on thirty six adult healthy male albino rats 3-6 months of age, each weighing from 150 to $200 \mathrm{gm}$. They were obtained from the Animal House Unit in the Faculty of Medicine, Zagazig University. All animals were retained in environmentally controlled rooms, in wire mesh cages \& kept under good hygienic conditions. They were fed on a balanced diet and water for two weeks before study [14]. The experimental procedures were approved by the ethical review committee of the Institutional Animal Care and Use Committee of Faculty of Medicine; Zagazig University (The number of IACUC approval is ZUIACUC/3/F/86/2019). The animals were equally divided into four groups ( 9 animals for each).

- Group I (control group): Animals received only balanced diet and water.

- Group II (Selenium treated group): Animals received daily dose of sodium selenite $(0.25 \mathrm{mg} / \mathrm{kg}$ B.W, in distilled water) [15] .

- Group III (Potassium Dichromate-treated Group): Animals were received daily dose of potassium dichromate (700ppm equivalent to $67 \mathrm{mg} / \mathrm{kg} \mathrm{B.W}$, in distilled water) [16].

- Group IV (Potassium dichromate and Seleniumtreated Group): Animals were received daily doses of potassium dichromate and sodium selenite (the same doses discussed in group III \& II). The previous chemicals were given to animals once daily by a feeding tube for four weeks [17] At the end of the experiment, the animals were anaesthetized with sodium phenobarbital intraperitoneal injection $(35 \mathrm{mg} / \mathrm{kg})$ body weight and blood samples from tail vein were collected for estimation of liver function tests. Liver specimens were taken for histopathological, immunohistochemical studies and real-time RT-PCR analysis of oxidative stress genes as follow:

\section{- Determination of plasma ALT, AST and bilirubin (total):}

Collected blood samples from the rats at the end of the experiment were centrifuged at 5000 $\mathrm{rpm}, 4^{\circ} \mathrm{C}$, for $15 \mathrm{~min}$; the plasma samples were stored at $-30^{\circ} \mathrm{C}$. AST, ALT analyzed by semiautomated clinical chemistry analyzer Microlab 300. AST and ALT were assayed according to the method of Reitman and Frankel [18], while bilirubin was assayed according to standard procedures as reported by Soudani et al., [19] .

\section{- RNA isolation and real-time RT-PCR:}

Total RNA was isolated from approximately $30 \mathrm{mg}$ of liver tissues using Gene JET RNA Purification Kit (Thermo Scientific, \# K0731, USA) 
according to the manufacturer's protocol. The purity and concentration of RNA were determined by Nano drop Spectrophotometer (Quawell Q5000; Quawell Technology) by measuring the absorbance at $260 / 280 \mathrm{~nm}$. The RNA was then reverse transcribed using RevertAid H Minus Reverse Transcriptase (Thermo Scientific). The created cDNA was used as a template to determine the relative expression of the CAT, GPx and SOD 1 genes using Rotor - Gene Q cycler (Qiagen, Germany) with 2X Maxima SYBR Green/ROX qPCR Master Mix (Thermo Scientific, \# K0221, USA) and genespecific primers (Table 1). The reactions were performed for all samples under the following thermal profile: 1 cycle at $95{ }^{\circ} \mathrm{C}$ for $30 \mathrm{~s}$ and 40 cycles of $15 \mathrm{~s}$ at $95^{\circ} \mathrm{C}, 60 \mathrm{~s}$ at $58.5^{\circ} \mathrm{C}$ and $2 \mathrm{~min}$ at $72^{\circ} \mathrm{C}$. Melting curves were produced at the end of the last cycle by increasing the temperature from $63^{\circ}$ to $95^{\circ} \mathrm{C}$ to confirm that a single product was amplified in the reaction. All reactions were run in triplicates. The reference gene $\beta$-actin was used as an internal control to calculate fold change in target genes. The relative mRNA expression levels of target genes of interest were calculated using the normalized relative quantification method followed by the $2 \Delta \Delta$ CT method [20].

Table (1): Primers used for real-time PCR amplifications [21]

\begin{tabular}{|c|c|c|}
\hline Gene & Sequence & $\begin{array}{l}\text { Size } \\
\text { (bp) }\end{array}$ \\
\hline CAT & $\begin{array}{l}\text { F.5'- TGCCGTCCGATTCTCCACAG-3' } \\
\text { R.5'- TCCCACGAGGTCCCAGTTAC-3' }\end{array}$ & 115 \\
\hline GPx & $\begin{array}{l}\text { F.5'- GTCCACCGTGTATGCCTTCTCC-3' } \\
\text { R.5'- TCTCCTGATGTCCGAACTGATTGC-3' }\end{array}$ & 218 \\
\hline SOD1 & $\begin{array}{l}\text { F.5'- ACACAAGGCTGTACCACTGC-3' } \\
\text { R.5'- CCACATTGCCCAGGTCTCC-3' }\end{array}$ & 103 \\
\hline$\beta$-actin & $\begin{array}{l}\text { F.5'- ACTATCGGCAATGAGCGGTTCC-3' } \\
\text { R.5'-CTGTGTTGGCATAGAGGTCTTTACG-3' }\end{array}$ & 148 \\
\hline
\end{tabular}

\section{- Histopathological study:}

Samples from liver were rapidly fixed in $10 \%$ formol saline for 48 hours, dehydrated through graded alcohols and embedded in paraffin. Transverse sections of 5 mickness were obtained from all specimens and prepared for staining with:

1- Hematoxylin and Eosin (H\&E) to describe the general histological hepatic structure [22]

2- Immuno-histochemical stain for detection of glial fibrillary acidic protein (GFAP): Universal kits for GFAP (Cambridge, Massachusetts, USA) were attained from Dako Company (Egypt). After de-paraffinization, rehydration, and rinsing in tap water, $\mathrm{H} 2 \mathrm{O} 2$ is used (to inhibit the endogenous peroxidase). Blocking solution was used to block the endogenous biotin. Later, incubation with diluted primary antibody for two hours (monoclonal mouse antibody for GFAP) is performed according to vendor's instructions. Positive and negative control slides were involved within each sitting. After that, phosphate-buffered saline was used for washing. Then, addition of streptavidinperoxidase drops for twenty minutes. After that washing with PBS for 5min. Finally, diaminobenzidine was supplemented and Mayer's hematoxylin was used as a counterstain. Replacement of the primary antibody with PBS was done for negative control $[\mathbf{2 3 , 2 4 ]}$.

\section{- Morphometric study:}

The morphometric study was done to detect the immuno-expression of GFAP positive HSCs (by detecting the brown color) using image analyzer software (Leica Qwin 500 Image Analyzer, England) in the Image Analyzing Unit of Human Anatomy and Embryology Department, Faculty of Medicine, Zagazig University, Egypt. It converted the measurement units (pixels) into micrometers automatically by calibration. Ten readings were obtained (five sections per rat in each group using the interactive measurement menu) and the means were calculated.

\section{- Statistical analysis:}

All data were statistically assessed with Statistical Package for Social Sciences (SPSS) version 20 (SPSS Inc., Chicago, Illinois, USA). one-way analysis of variance (ANOVA), followed by Tukey's Honestly Significant Difference (Tukey's HSD) test as post hoc test was used. A significant or highly significant difference was present with $p$ values less than 0.05 or 0.01 respectively. All the numerical results were expressed as mean \pm S.D.

\section{Results}

\section{1- Biochemical results:}

\section{- Serum level of ALT, AST and total bilirubin:}

The serum levels of ALT, AST and total bilirubin in the present study showed no statistical significant difference between group I (control) and group II (Se-group). But a high statistical significant increase $(p<0.001)$ was detected in group III (Cr-treated) as compared with groups (I and II) and a statistical significant decrease was detected in group IV $(\mathrm{Cr}$ $\&$ Se-group) as compared with group III ( $\mathrm{Cr}$ treated), however, their levels were still statistically significant more than those in group I (control) and group II (Se-group) (Table 2). 
Table (2): Statistical analysis of liver function tests of Aspartate aminotransferase (AST), Alanine aminotransferase (ALT) and total bilirubin in the different studied groups using one way analysis of variance (ANOVA) with post hoc Tukey test. (data was expressed as Mean $\pm \mathrm{SD}$. number of rats=9).

\begin{tabular}{|c|c|c|c|c|}
\hline & $\begin{array}{l}\text { Group I } \\
\text { (control) }\end{array}$ & $\begin{array}{c}\text { Group II } \\
\text { (Se-group) }\end{array}$ & $\begin{array}{l}\text { Group III } \\
\text { (Cr-treated) }\end{array}$ & $\begin{array}{c}\text { Group IV } \\
\text { (Cr-\& Se-group) }\end{array}$ \\
\hline ALT (U/L) & $56.8 \pm 12.2$ & $\begin{array}{l}61.1 \pm 19.8 \\
\text { NS a }\end{array}$ & $\begin{array}{l}99 \quad 8.8 \\
\mathbf{a}_{\mathbf{b} p}<0.001 * *\end{array}$ & $\begin{array}{l}81.6 \pm 10.3 \\
\mathbf{a} p<0.01 \\
\mathbf{b}, c_{p}<0.05\end{array}$ \\
\hline AST (U/L) & $127.8 \pm 6.7$ & $\begin{array}{l}134.3 \pm 8.9 \\
\text { NS a }\end{array}$ & $\begin{array}{l}270.8 \pm 49.8 \\
\mathbf{a}^{\prime} \mathbf{b}_{p}<0.001\end{array} * *$ & $\begin{array}{l}171.1 \pm 22.6 \\
\mathbf{a} \cdot \mathbf{b} p<0.05 \\
\mathbf{c}_{\mathrm{p}}<0.001 * *\end{array}$ \\
\hline$\underset{(\mathrm{mg} / \mathrm{l})}{\text { Bilirubin }}$ & $0.61 \pm 0.06$ & $\begin{array}{l}0.75 \pm 0.04 \\
\text { NS a }\end{array}$ & $\begin{array}{l}1,68 \pm 0.26 \\
\mathbf{a} ; \mathbf{b}_{p}<0.001 * *\end{array}$ & $\begin{array}{l}0,94 \pm 0.08 \\
\mathbf{a}^{\mathbf{a}} \mathbf{c}_{p<0.001} \\
\mathbf{b}_{p<0.05}<*\end{array}$ \\
\hline
\end{tabular}

SD: Standard deviation. NS: Non-significant.

- The different superscripts denote significant and high significant difference at $(p<0.05$ and $p<0.001)$ respectively ( $\mathbf{a}=$ versus groupI, $\mathbf{b}=$ versus group-II, and $\mathbf{c}=$ versus group-III)

\section{2- Gene expression analysis:}

- The effect of $\mathrm{Cr}$ (VI) treatment on the antioxidative stress related genes (CAT, SOD1 and GPx) relative mRNA expression were examined by qPCR in rat liver is shown in (Table 3 ). The results revealed that there was no statistical significant difference between control and Se treated rats. But in $\mathrm{Cr}$ treated group (III) a significant down regulation of the expression levels of CAT, SOD1 and GPx observed as compared to control $\&$ Se-group $(p<0.05)$. In contrast, Se coadministration with $\mathrm{Cr}$, up regulated CAT, SOD1 and GPx gene expression levels in comparison to $\mathrm{Cr}$ treated animals, but, their levels were still statistically significant less than those in group I (control) and group II (Se-group).

Table (3): Statistical analysis of Real-time RT-PCR of antioxidative stress-related genes CAT, GPx and SOD1 mRNA expression in rat liver of different studied groups. Data was expressed as mean \pm S.E. $(n=9)$. The different superscripts denote significant differences at $(p<0.05)$ based on Tukey's Honestly Significant Difference (Tukey's HSD) test.

\begin{tabular}{|c|c|c|c|c|}
\hline & $\begin{array}{l}\text { Group I } \\
\text { (control) }\end{array}$ & $\begin{array}{c}\text { Group II } \\
\text { (Se-group) }\end{array}$ & $\begin{array}{c}\text { Group III } \\
\text { (Cr-treated) }\end{array}$ & $\begin{array}{c}\text { Group IV } \\
\text { Cr-\& Se-group) }\end{array}$ \\
\hline CAT & $1.02 \pm 0.05$ & $\begin{array}{l}1.12 \pm 0.08 \\
\mathrm{NSa}\end{array}$ & $\begin{array}{l}0.32 \pm 0.03 \\
\mathbf{a} \cdot \mathbf{b} p<0.05\end{array}$ & $\begin{array}{l}0.54 \pm 0.04 \\
\mathbf{a}^{\prime} \mathbf{b}^{\prime} \mathbf{c}<<0.05\end{array}$ \\
\hline GPx & $1 \pm 0.1$ & $\begin{array}{l}0.95 \pm 0.09 \\
\text { NSa }\end{array}$ & $\begin{array}{l}0.16 \pm 0.03 \\
\mathbf{a}^{\prime} \mathbf{b} p_{<0.05}\end{array}$ & $\begin{array}{l}0.46 \pm 0.05 \\
\mathbf{a}^{\prime} \mathbf{b} \mathbf{c}^{\prime} \mathbf{c}<0.05\end{array}$ \\
\hline SOD1 & $1.21 \pm 0.07$ & $\begin{array}{l}1.01 \pm 0.06 \\
\mathrm{NSa}\end{array}$ & $\begin{array}{l}0.27 \pm 0.05 \\
\mathbf{a} \cdot \mathbf{b} p<0.05\end{array}$ & $\begin{array}{l}0.56 \pm 0.08 \\
\mathbf{a}^{\prime} \mathbf{b} \mathbf{c}^{\prime} \mathbf{p}<0.05\end{array}$ \\
\hline
\end{tabular}

SD: Standard deviation. NS: Non-significant.

- The different superscripts denote significant and high significant difference at $(p<0.05$ and $p<0.001)$ respectively ( $\mathbf{a}=$ versus group$\mathrm{I}, \mathbf{b}=$ versus group-II, and $\mathbf{c}=$ versus group-III).

\section{3- Histological examination:}

\section{A- Hematoxylin \& Eosin stains:}

Hepatic sections of control group (I) and Se treated group (II) showed the same histological structure, where the hepatic lobules appeared normally with polygonal hepatocytes having acidophilic cytoplasm and rounded vesicular nuclei. The hepatocytes were arranged in cords radiating from the central vein with blood sinusoids between the hepatic cords. Normal appearance of portal area with portal triads containing branches of portal vein, hepatic artery and bile duct (Fig.1A $\left.\& \mathrm{~A}^{*}\right)$.

In Cr-treated group (III) the sections showed marked loss of normal hepatic architecture with slightly dilated central vein. The hepatocytes appeared with ill-defined borders, dark stained pyknotic nuclei and others with vacuolated cytoplasm indicating presence of hepatocellular degeneration. Some cells showed peripherally placed nuclei (signet ring appearance) indicating the presence of fatty degeneration. In addition, the portal area showed dilated congested portal vein with thick wall, mononuclear cellular infiltration, bile duct proliferation with thickening of the wall and stratification of the lining epithelium. Dilated sinusoids can be noticed (Fig.1B \& B*).

$\mathrm{Cr}$ and Se-treated group (IV) showed apparent restoration of the normal hepatic structure with less mononuclear cellular infiltration, as compared to group (III). The central vein appeared slightly dilated. Most of the hepatocytes appeared with vesicular nuclei (few with pyknotic nuclei), acidophilic cytoplasm with small vacuoles in some and others were binucleated with normal appearance of the portal triads (Fig.1C \& $\mathrm{C}^{*}$ ).

\section{B-Immuno-histochemical stain for GFAP:}

Liver sections of control group showed negative immune reaction for (GFAP) as detected by absence of the brown color, while $\mathrm{Cr}$ treated group (III) showed apparent increase in positive immune reaction of (HSCs) for (GFAP) as detected by increased brown color. On the other hand $\mathrm{Cr} \& \mathrm{Se}$ treated group (IV) showed apparent decrease in positive immune reaction of (HSCs) for (GFAP) as noticed by decreased brown color in between hepatocytes (Fig. 2A, B \& C). 

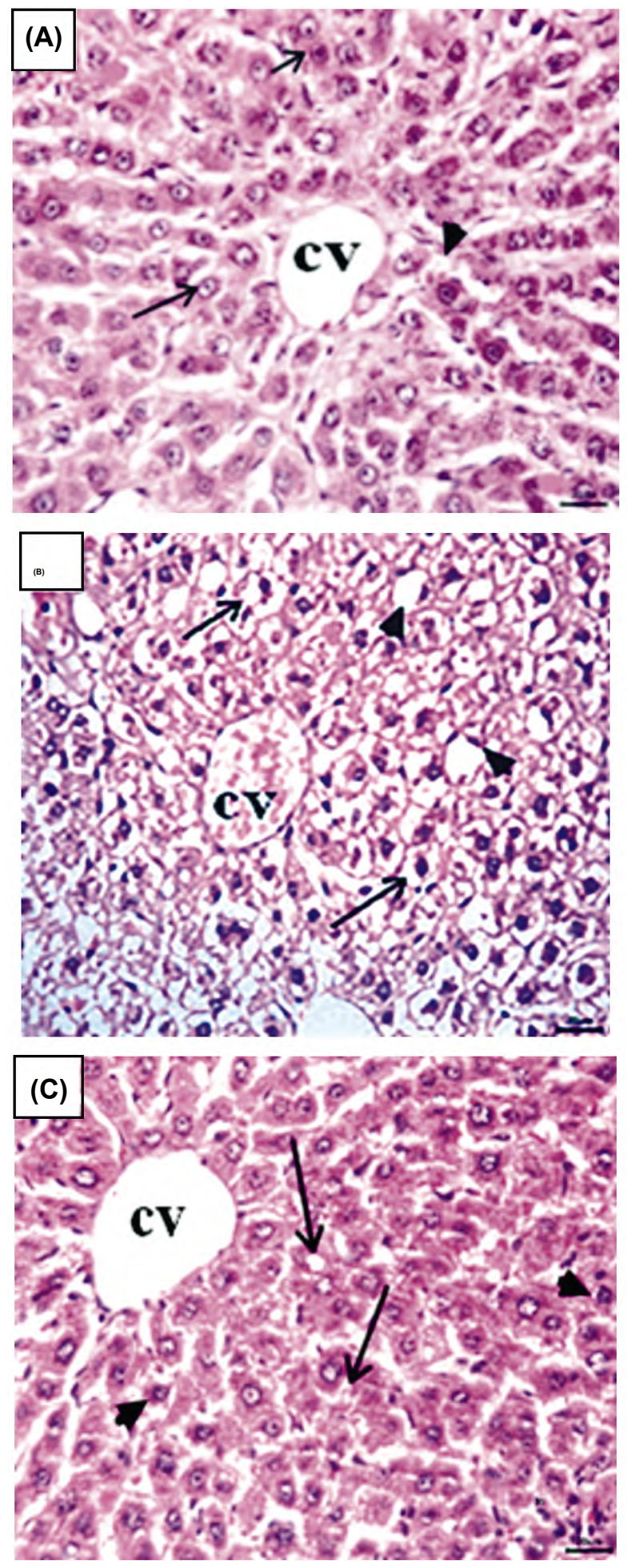
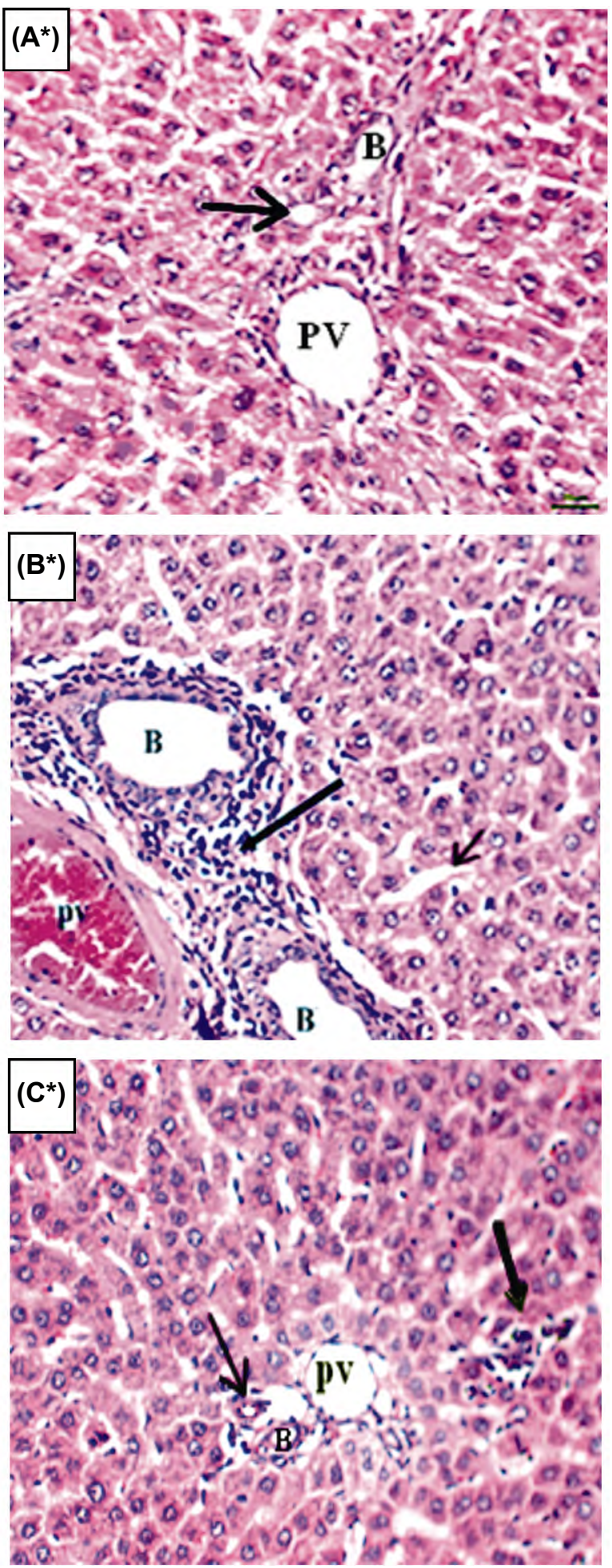

Fig. (1): A photomicrograph of a section in the liver of the control groups (A and A*). A: Shows polygonal hepatocytes with acidophilic cytoplasm radiating from central vein (CV) with rounded vesicular nuclei and acidophilic cytoplasm (long arrow), binucleated cells are also seen (short arrow) and narrow radiating blood sinusoids (arrow head) in between liver cords. A*: shows portal area containing branches of portal vein (PV), hepatic artery (arrow) and bile duct (B). Cr treated group (B and $\left.\mathrm{B}^{*}\right) \mathrm{B}$ : Shows loss of the normal arrangement of hepatocytes with slightly dilated central vein (CV), hepatocytes with degenerated vacuolated cytoplasm (arrows) with presence of cells with peripheral placed nuclei (signet ring appearance) (arrow heads) B*: shows dilated congested portal vein with thick wall (PV), mononuclear cellular infiltration (arrow), bile duct proliferation (B) with thickening of the wall \& stratification of the lining epithelium and some sinusoids show slight dilatation (short arrow). $\mathrm{Cr}$ and Se treated group $\left(\mathrm{C}\right.$ and $\left.\mathrm{C}^{*}\right) \mathrm{C}$ : Shows apparent restoration of the normal hepatic structure with slightly dilated central vein (CV), some hepatocytes show vacuoles within their cytoplasm (long arrow) and others appear with pyknotic nuclei (arrow heads). C*: Shows apparent normal arrangement of portal area with branches of portal vein (PV), bile duct (B) and hepatic artery (arrow), few mononuclear cell infiltrations (thick arrow) (H\&E 400). 

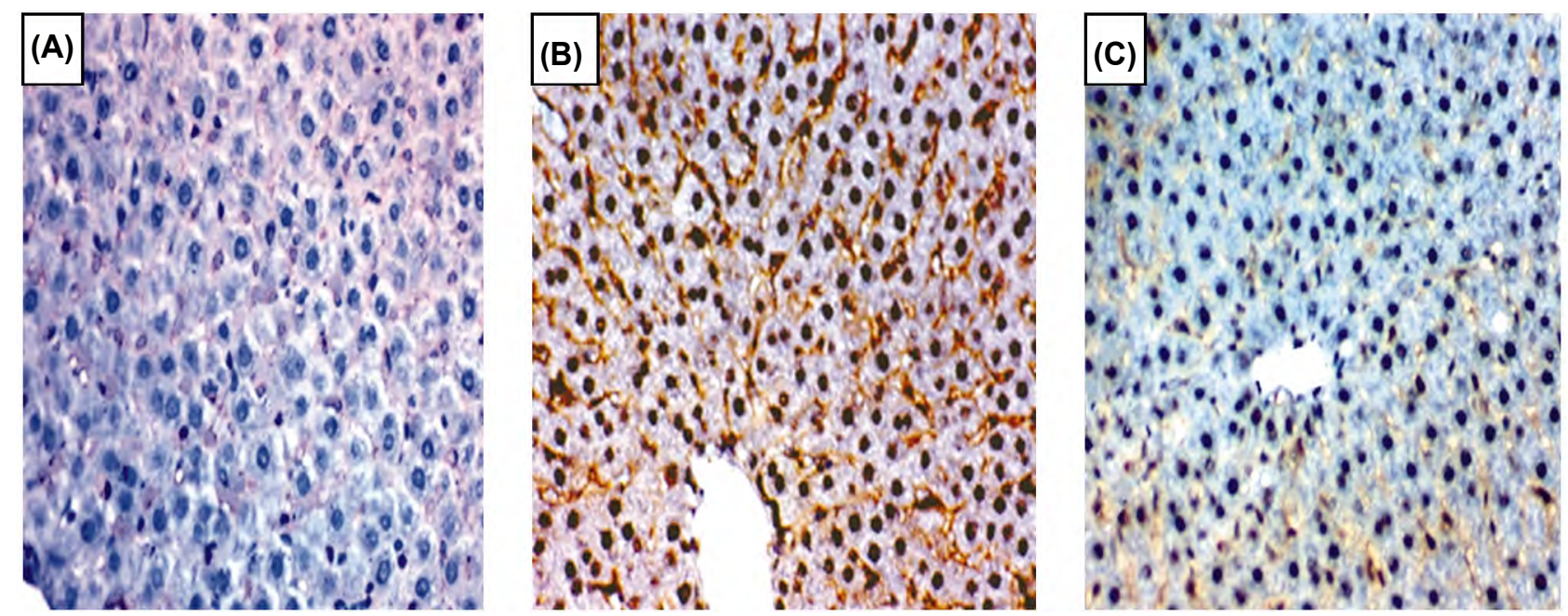

Fig. (2): Photomicrographs of glial fibrillary acidic protein (GFAP) immuno-histochemical-stained liver sections. (A): Control group showing negative immune reaction for (GFAP). (B): $\mathrm{Cr}$ treated group (III) showing obvious positive immune reaction for (GFAP). (C): Cr \& Se treated group (IV) showing apparent decrease in positive immune reaction for (GFAP) (X 400).

\section{4- Morphometric results of glial fibrillary acidic protein (GFAP) immune-expression:}

Examination of immune-hi stochemic ally stained sections of the area fractions of hepatic parenchyma occupied by GFAP-positive hepatic stellate cells in the periportal, pericentral and perisinusoidal areas of control group (I) and Segroup (II) revealed no statistical significant difference, however, Cr-treated group (III) showed high statistical significant increase in the GFAP area fraction (detected by marked increase in the brown color) as compared with groups I and II. But $\mathrm{Cr}$ and Se-group (IV) showed high statistical significant decrease as compared with group (III) but, still statistically significant more than that of groups (I \& II) (Table 4).

Table (4): Statistical analysis of morphometric results of Glial fibrillary acidic protein expression (GFAP) in the different studied groups by one way analysis of variance (ANOVA) with post hoc Tukey test. (Data was expressed as Mean \pm SD. Number of rats=9).

\begin{tabular}{lllll}
\hline & $\begin{array}{c}\text { Group I } \\
\text { (control) }\end{array}$ & $\begin{array}{c}\text { Group II } \\
\text { (Se-group) }\end{array}$ & \multicolumn{1}{c}{ Group III } & \multicolumn{1}{c}{$\begin{array}{c}\text { Group IV } \\
\text { (Cr-treated) }\end{array}$} \\
$($ Cr-\& Se-group)
\end{tabular}

SD: Standard deviation. NS: Non-significant.

- The different superscripts denote significant and high significant difference at $(p<0.05$ and $p<0.001)$ respectively ( $\mathrm{a}=$ versus group$\mathrm{I}, \mathrm{b}=$ versus group-II, and $\mathrm{c}=$ versus group-III).

\section{Discussion}

Chromium (VI) is a poisonous metal commonly used in industrial field. It produces toxic effects in the liver and other different organs [25]. This study, proved that Se ameliorated $\mathrm{Cr}$ induced hepatic injury. This was proved by biochemical, gene expression, histopathological and morphometric studies.

In the current study, $\mathrm{Cr}$ produced a high significant increase in the serum level of liver enzymes (AST and ALT), this is in agreement with previous studies of Soudani et al., [19] \& El-Demerdash et al., [26], who explained this due to their release from the cytoplasm indicating damage of liver tissue. In addition, other studies attributed this due to occurrence of oxidative stress process and consumption of the liver glutathione (GSH), that is one of the main antioxidant defense elements $[27,28]$ Another study explained that, plasma concentration of ALT is higher than AST in the cytoplasm so it is markedly elevated than AST in cases of inflammations or infections. But, in infiltrative diseases that damage the cytoplasmic \& mitochondrial membranes, the AST is higher than ALT [29]

The current study showed a statistical significant increase in plasma level of total bilirubin in $\mathrm{Cr}$ treated group (III) as compared with other groups. This elevation of bilirubin level is considered a strong evidence of disturbed liver functions, as reported by El-Demerdash et al., [26] who proved the same results.

On the other hand, in $\mathrm{Cr}$ and Se-group (IV) the plasma levels of ALT, AST and bilirubin showed statistical significant decrease as compared with Cr-treated group (III), these results are in agreement with those of Soudani et al., [19] who explained this effective role of Se due to inhibition of the oxidative stress, improvement of the activities of 
the antioxidant enzymes in addition to limiting the lipid peroxidation leading to restoration of the cell membrane lipid molecules. Moreover, Hegazy et al., [30] proved similar protective effect of vit. E against hepatotoxic effect of zinc oxide nanoparticles in rats.

Kirman et al., [31] \& Ovesen et al., [32] proved that $\mathrm{Cr}$ induced a significant effect on gene expression regulation as it lead to up regulation of oxidative stress genes. Protection of the cell from the harmful effects of oxidative stress process can occur through the protective role of antioxidant enzymes as Superoxide dismutase (SOD) which is a metallo-protein, Catalase (CAT) that is a hemoprotein which activates the reduction of $\mathrm{H} 2 \mathrm{O} 2$ to oxygen \& water and Glutathione peroxidase (GPx), that is a seleno-enzyme which plays an important role in the reduction of $\mathrm{H} 2 \mathrm{O} 2$ and hydroperoxide to non-toxic products $[33,34]$.

The results of this study revealed that administration of Cr orally significantly down regulated the expression levels of CAT, SOD1 and GPx as compared to control rats. Soudani et al., [18] found a decrease in glutathione peroxidase (GPx), But, an increase in superoxide dismutase (SOD) and catalase (CAT) activities due to the effect of $\mathrm{Cr}$. In this study, $\mathrm{Se}$ co-administration with $\mathrm{Cr}$ in group (IV), significantly up regulated CAT, SOD1 and GPx gene expression levels in comparison to $\mathrm{Cr}$ treated group (III). This protective effect of Se was explained due to its activation of the antioxidant enzymes (GPx, CAT \& SOD) as reported by previous studies $[\mathbf{3 5 , 3 6}]$.

Moreover, genotoxic effect of $\mathrm{Cr}$ may result from the creation of DNA adducts that produce DNA DSB which in turn stimulate the phosphorylation of histone H2AX in Ser-139 [37] .

The previous mentioned biochemical and genetic explanations were confirmed by hepatic histopathological changes observed in Cr-treated group (III), in the form of loss of normal hepatic architecture, dilatation of the central and dilated congested portal veins with mononuclear cellular infiltrations. Most of the hepatocytes showed degenerative changes, vacuolization of the cytoplasm and others appeared with signet ring appearance indicating fatty degeneration. These findings are in agreement with the results of previous studies [38]. Some sinusoids showed slight dilatation that may be due to change of (HSCs) into myofibroblasts, under the effect of cytokines released from liver injury. These myofibroblasts have contraction and fibrogenic activity [39]. The bile ducts showed proliferation with stratifications in some branches, this could be a response to hepatic injury that stimulated the proliferation and differentiation of hepatic stem cells into either hepatic cells or biliary epithelial cells, as proved by Richardson et al., [40].

The previous different pathological disorders were attributed to the effect of oxidative stress process \& toxic radicals induced by $\mathrm{Cr}$. The oxidative stress process occurs due to cellular reduction of $\mathrm{Cr}$ (VI) into $\mathrm{Cr}$ (III) that causes generation of reactive oxygen radicals (ROS) that in turn induce damage to the main components of the cell (proteins, lipids \& genetic material). In addition, these toxic oxidants cause lipid peroxidation which changes the integrity of the cell membrane, so affecting all cell functions [41,42].

The results of this study showed that Se coadministration with $\mathrm{Cr}$ in group (IV) improved the previous hepatic histopathological changes where there were restoration of normal hepatic architecture, decreased the cell infiltrations \& most of the hepatocytes showed normal appearance with acidophilic cytoplasm \& vesicular nuclei. These results were in accordance with those of Amraoui et al., [43] who proved the protective effect of selenium, vitamin $\mathrm{E}$ and natural antioxidants, against Bisphenol A-induced oxidative stress in albino rats.

Different studies explained the repairing effect of Se due to its role as antioxidant in preventing the oxidative process of the membranous components, and preventing the chromium induced toxicity through forming a capsule around the toxin or even eliminating it from the body, so it is important for chelation therapy $[35,36]$.

Immuno-histochemical stained sections of the area fractions of hepatic parenchyma occupied by GFAP-positive hepatic stellate cells in the periportal, pericentral and perisinusoidal areas of $\mathrm{Cr}$ treated group (III) showed high statistical significant increase in the GFAP area fraction (detected by marked increase in the brown color) as compared with groups I and II. This is in agreement with the findings of Hassan et al., [44] who explained this due to rapid reaction of (HSCs) under the effect of chemical mediators released from the inflammatory cells or Kupffer cells during acute hepatic injury, particularly as they are in close contact to the sinusoids. These chemical mediators in turn induce more stimulation of the HSCs and their transformation into myofibroblast like cells. The transformed HSCs show expression of certain mesenchymal indicators as Alpha Smooth Muscle 
Actin ( $\alpha$-SMA) \& Glial Fibrillary Acidic Protein (GFAP). The latter represents a more important early indicator of HSCs as compared with ( $\alpha$ SMA) [45,46]. Moreover, Yan et al., [47] reported that HSCs are stimulated due to Hedgehog $(\mathrm{Hh})$ signaling pathway-related molecules that are released due to $\mathrm{Cr}$ induced liver injury.

\section{Conclusion:}

This study proved that the chromium induced toxicity which changed the activities of antioxidant enzymes and induced histopathological damage of the liver tissue leading to biochemical disturbances in the levels of liver enzymes and total bilirubin. These hepatic structural and functional damage were less manifested by co-administration of $\mathrm{Se}$ with the $\mathrm{Cr}$. So, care must be taken into consideration during $\mathrm{Cr}$ exposure and it is recommended to take antioxidants as Se to decrease the harmful effects of Cr.

\section{Disclosure:}

All authors state that they did not receive any fund for performing this study and that they have no conflicts of interest.

\section{References}

1- O'BRIEN T.J., CERYAK S. and PATIERNO S.R.: Complexities of chromium carcinogenesis: Role of cellular response, repair and recovery mechanisms. Mutat. Res., 533 (1-2): 336. doi: 10.1016/j.mrfmmm. 09.006, 2003.

2- XU X.R., LI H.B., LI X.Y. and GU J.D.: Reduction of hexavalent chromium by ascorbic acid in aqueous solutions. Chemosphere, 57 (7): 609-613, 2004.

3- SAFETY O. and ADMINISTRATION H.: Occupational exposure to hexavalent chromium. Final rule. Federal register, 71 (39): 10099, 2006.

4- SALNIKOW K. and ZHITKOVICH A.: Genetic and epigenetic mechanisms in metal carcinogenesis and cocarcinogenesis: Nickel, arsenic, and chromium. Chemical research in toxicology, 21 (1): 28-44, 2007.

5- PEDRAZA-CHAVERRÍ J., BARRERA D., MEDINACAMPOS O.N., CARVAJAL R.C., HERNÁNDEZ-PANDO R., MACÍAS-RUVALCABA N.A. and SALDÍVAR L.: Time course study of oxidative and nitrosative stress and antioxidant enzymes in $\mathrm{K} 2 \mathrm{Cr} 2 \mathrm{O} 7$-induced nephrotoxicity. BMC. nephrology, 6 (1): 4, 2005.

6- BO SGELMEZ I.I., SÖYLEMEZO GLUU T. and GÜVENDIK G.: The protective and antidotal effects of taurine on hexavalent chromium-induced oxidative stress in mice liver tissue. Biological trace element research, 125 (1): 46, 2008.

7- PUCHE J.E., LEE Y.A., JIAO J., ALOMAN C., FIEL M.I., MUÑOZ U. and FRIEDMAN S.L.: A novel murine model to deplete hepatic stellate cells uncovers their role in amplifying liver damage in mice. Hepatology, 57 (1): 339-350, 2013.
8- PATEL P., KHAN N., RANI M., GUPTA D. and JAMEEL S.: The expression of HIV-1 Vpu in monocytes causes increased secretion of TGF- $\beta$ that activates profibrogenic genes in hepatic stellate cells. PloS. one, 9 (2): e88934, 2014.

9- WANG B.B., CHENG J.Y., GAO H.H., ZHANG Y., CHEN Z.N. and BIAN H.: Hepatic Stellate Cells in Inflammation - Fibrosis - Carcinoma Axis. The Anatomical Record: Advances in Integrative Anatomy and Evolutionary Biology, 293 (9): 1492-1496, 2010.

10- BARANOVA A., LAL P., BIRERDINC A. and YOUNOSSI Z.M.: Non-invasive markers for hepatic fibrosis. BMC. gastroenterology, 11 (1): 91, 2011.

11- ZAKARIA S., YOUSSEF M., MOUSSA M., AKL M., EL-AHWANY E., EL-RAZIKY M. and EL-HINDAWI A.: Value of $\alpha$-smooth muscle actin and glial fibrillary acidic protein in predicting early hepatic fibrosis in chronic hepatitis $\mathrm{C}$ virus infection. Archives of medical science: AMS, 6 (3): 356-365. doi: 10.5114/aoms. 2010. 14255, 2010.

12- OGNJANOVI C'B.L, MARKOVI C' S.D., PAVLOVIC, S.Z.,ZIKI C' R.V. and STAJN A.: Effect of chronic cadmium exposure on antioxidant defense system in some tissues of rats: Protective effect of selenium. Physiological research, 57 (3), 2008.

13- JYOTHIP D., P,P. and V S.: Hepatoprotective effect of selenium and trichuriella monsoniae against cadmium induced liver toxicity in rats. International Journal of Advanced Research, 5: 2224-2230. doi: 10. 21474/ IJAR01/4963, 2017.

14- SENGUPTA, P.: A scientific review of age determination for a laboratory rat: How old is it in comparison with human age. Biomed Int., 2 (2): 81-89, 2011.

15- ASLANTURK A., UZUNHISARCIKLI M., KALENDER S. and DEMIR F.: Sodium selenite and vitamin E in preventing mercuric chloride induced renal toxicity in rats. Food and Chemical Toxicology, 70: 185-190, 2014.

16- SOUDANI N., SEFI M., AMARA I.B., BOUDAWARA T. and ZEGHAL N.: Protective effects of selenium (Se) on chromium (VI) induced nephrotoxicity in adult rats. Ecotoxicology and environmental safety, 73 (4): 671-678, 2010.

17- DEY S.K., DOLAI D.P., DASH S.K., MANDAL D., DAS B. and ROY S.: Sodium Selenite Attenuates ChromiumInduced Membrane Damage. Eur. J. Health. Sci., 2 (3): 89-97, 2016.

18- REITMAN S. and FRANKEL S.: A colorimetric method for the determination of serum glutamic oxalacetic and glutamic pyruvic transaminases. American journal of clinical pathology, 28 (1): 56-63, 1957.

19- SOUDANI N., AMARA I.B., SEFI M., BOUDAWARA T. and ZEGHAL N.: Effects of selenium on chromium (VI)-induced hepatotoxicity in adult rats. Experimental and toxicologic pathology, 63 (6): 541-548, 2011.

20- LIVAK K.J. and SCHMITTGEN T.D.: Analysis of relative gene expression data using real-time quantitative PCR and the 2- $\Delta \Delta C T$ method. methods, 25 (4): 402-408, 2001.

21- XU Z., WANG Z., LI J.J., CHEN C., ZHANG P.C., DONG L. and WANG Z.L.: Protective effects of selenium on oxidative damage and oxidative stress related gene ex- 
pression in rat liver under chronic poisoning of arsenic Food and Chemical Toxicology, 58: 1-7, 2013.

22- KIERNAN J.A.: Histological and histochemical methods: Theory and practice. Shock, 12 (6): 479, 1999.

23- BARATTA J.L., NGO A., LOPEZ B., KASABWALLA N., LONGMUIR K.J. and ROBERTSON R.T.: Cellular organization of normal mouse liver: A histological, quantitative immunocytochemical, and fine structural analysis. Histochem Cell Biol, 131(6): 713-726. doi: 10.1007/ s00418-009-0577-1, 2009.

24- HASSAN N., SOLIMAN G., OKASHA E. and SHALABY A.: Histological, immunohistochemical, and biochemical study of experimentally induced fatty liver in adult male albino rat and the possible protective role of pomegranate. Journal of Microscopy and Ultrastructure, 6 (1): 44-55. doi: 10.4103/jmau.jmau_5_18, 2018.

25- SÁNCHEZ-MARTÍN F.J., FAN Y., CARREIRA V., OVESEN J.L., VONHANDORF A., XIA Y. and PUGA A.: Long-term coexposure to hexavalent chromium and $\mathrm{B}$ [a] $\mathrm{P}$ causes tissue-specific differential biological effects in liver and gastrointestinal tract of mice. Toxicological Sciences, 146 (1): 52-64, 2015.

26- EL-DEMERDASH F.M., YOUSEF M.I. and ELASWAD F.A.: Biochemical study on the protective role of folic acid in rabbits treated with chromium (VI). Journal of Environmental Science and Health Part. B., 41 (5): 731746,2006

27- ROMÃO P., TOVAR J., FONSECA S., MORAES R., CRUZ A., HOTHERSALL J. and CUNHA F.: Glutathione and the redox control system trypanothione/trypanothione reductase are involved in the protection of Leishmania spp. Against nitrosothiol-induced cytotoxicity. Brazilian Journal of Medical and Biological Research, 39 (3): 355363,2006

28- GUNARATNAM M. and GRANT M.H.: Cr (VI) inhibits DNA, RNA and protein syntheses in hepatocytes: involvement of glutathione reductase, reduced glutathione and DT-diaphorase. Toxicology in vitro, 22 (4): 879-886, 2008.

29- AKILA G., RAJAKRISHNAN V., VISWANATHAN P., RAJASHEKARAN K. and MENON V.P.: Effects of curcumin on lipid profile and lipid peroxidation status in experimental hepatic fibrosis. Hepatology research, 11 (3): 147-157, 1998.

30- HEGAZY A., AHMED M., SHEHATA M. and ABDELFATTAH M.: Changes in Rats' Liver Structure Induced by Zinc Oxide Nanoparticles and the Possible Protective Role of Vitamin E. International Journal of Human Anatomy, 1, 1-16. doi:10.14302/issn. 2577-2279.ijha-18-2384, 2018.

31- KIRMAN C., AYLWARD L., SUH M., HARRIS M., THOMPSON C., HAWS L. and HAYS S.: Physiologically based pharmacokinetic model for humans orally exposed to chromium. Chemico-biological interactions, 204 (1): 13-27, 2013.

32- OVESEN J.L., FAN Y., ZHANG X., CHEN J., MEDVEDOVIC M., XIA Y. and PUGA A.: Formaldehyde-Assisted Isolation of Regulatory Elements (FAIRE) analysis uncovers broad changes in chromatin structure resulting from hexavalent chromium exposure. PloS one, 9 (5): p. e97849-e97849, 2014
33- MCCORD J.M., KEELE B.B. and FRIDOVICH I.: An enzyme-based theory of obligate anaerobiosis: The physiological function of superoxide dismutase. Proceedings of the National Academy of Sciences, 68 (5): 1024-1027, 1971.

34- FREEMAN B.A. and CRAPO J.D.: Biology of disease: free radicals and tissue injury. Lab Invest, 47 (5): 412 426, 1982.

35- TALAS Z.S., ORUN I., OZDEMIR I., ERDOGAN K., ALKAN A. and YILMAZ I.: Antioxidative role of selenium against the toxic effect of heavy metals $(\mathrm{Cd}+2$, $\mathrm{Cr}+3$ ) on liver of rainbow trout (Oncorhynchus mykiss Walbaum 1792). Fish physiology and biochemistry, 34 (3): 217-222, 2008.

36- LAZARUS M., ORCT T., JURASOVIÆ J. and BLANUSA M.: The effect of dietary selenium supplementation on cadmium absorption and retention in suckling rats. BioMetals, 22 (6): 973-983. doi:10.1007/s 10534-009. 9249-9, 2009.

37- LUKAS J., LUKAS C. and BARTEK J.: More than just a focus: The chromatin response to DNA damage and its role in genome integrity maintenance. Nature cell biology, 13 (10): 1161-1169, 2011

38- KALAYARASAN S., SRIRAM N., SURESHKUMAR A. and SUDHANDIRAN G.:Chromium (VI)-induced oxidative stress and apoptosis is reduced by garlic and its derivative $\mathrm{S}$-allylcysteine through the activation of Nrf 2 in the hepatocytes of Wistar rats. J. Appl. Toxicol., 28 (7): 908-919. doi:10.1002/jat.1355, 2008.

39- CARLONI V., LUONG T.V. and ROMBOUTS K.: Hepatic stellate cells and extracellular matrix in hepatocellular carcinoma: More complicated than ever. Liver. Int., 34 (6): 834-843. doi: 10.1111/liv.12465, 2014.

40- RICHARDSON M.M., JONSSON J.R., POWELL E.E., BRUNT E.M., NEUSCHWANDER-TETRI B.A., BHATHAL P.S. and CLOUSTON A.D.: Progressive fibrosis in nonalcoholic steatohepatitis: Association with altered regeneration and a ductular reaction. Gastroenterology, 133 (1): 80-90. doi:10.1053/j.gastro. 2007.05.012, 2007.

41- ACHARYA U.R., MISHRA M., TRIPATHY R.R. and MISHRA I.: Testicular dysfunction and antioxidative defense system of Swiss mice after chromic acid exposure. Reprod Toxicol, 22 (1): 87-91. doi: 10.101 6/j.reprotox. 2005.11.004, 2006.

42- BANU S.K., SAMUEL J.B., AROSH J.A., BURGHARDT R.C. and ARULDHAS M.M.: Lactational exposure to hexavalent chromium delays puberty by impairing ovarian development, steroidogenesis and pituitary hormone synthesis in developing Wistar rats. Toxicology and Applied Pharmacology, 232 (2): 180-189. doi: https://doi. . org/10.1016/j.taap. 2008. 06.002, 2008.

43- AMRAOUI W., ADJABI N., BOUOUZA F., BOUMENDJEL M., TAIBI F., BOUMENDJEL A. and MESSARAH M.: Modulatory Role of Selenium and Vitamin E, Natural Antioxidants, against Bisphenol A-Induced Oxidative Stress in Wistar Albinos Rats. Toxicological research, 34 (3): 231-239. doi:10.5487/TR.2018. 34.3.231, 2018.

44- HASSAN S., SYED S. and KEHAR S.I.: Glial Fibrillary Acidic Protein (GFAP) as a Mesenchymal marker of Early Hepatic Stellate Cells Activation in Liver Fibrosis in 
Chronic Hepatitis C Infection. Pak J Med Sci, 30 (5): 1027-1032. doi:10.12669/pjms. 305.5534, 2014.

45- CAROTTI S., MORINI S., CORRADINI S.G., BURZA M.A., MOLINARO A., CARPINO G. and GAUDIO E.: Glial fibrillary acidic protein as an early marker of hepatic stellate cell activation in chronic and posttransplant recurrent hepatitis C. Liver Transpl, 14 (6): 806-814. doi: 10.1002/lt.21436, 2008.

46- TAKAHASHI T., YOSHIOKA M., UCHINAMI H., NAKAGAWA Y., OTSUKA N., MOTOYAMA S. and
YAMAMOTO Y.: Hepatic Stellate Cells Play a Functional Role in Exacerbating Ischemia-Reperfusion Injury in Rat Liver. European Surgical Research. Europaische Chirurgische Forschung. Recherches Chirurgicales Europeennes, 60 (1-2): 74-85. doi: 10.1159/000499750, 2019.

47- YAN J., HUANG H., LIU Z., SHEN J., NI J., HAN J. and JIN L.: Hedgehog signaling pathway regulates hexavalent chromium-induced liver fibrosis by activation of hepatic stellate cells. Toxicology Letters, 320: 1-8. doi: https:// . doi. org/10.1016/i.toxlet. 2019. 11.017, 2020.

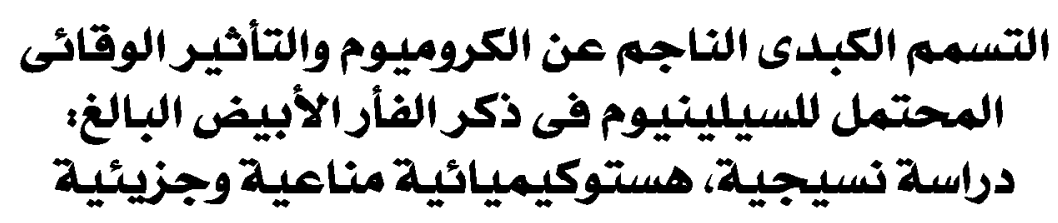

مقدمة: يعد الكروميوم (ثنائى كرومات البوتاسيوم) ملوث بيئى يشتهر بآتاره السامة الخطيرة التى تسبب مخاطر محية متعددة. آما السلينيوم

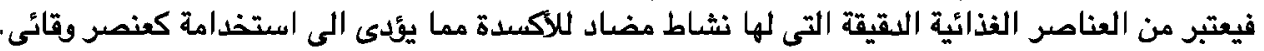

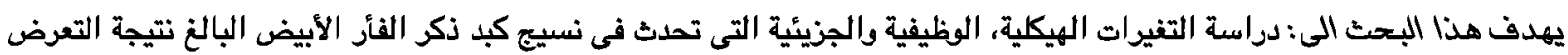

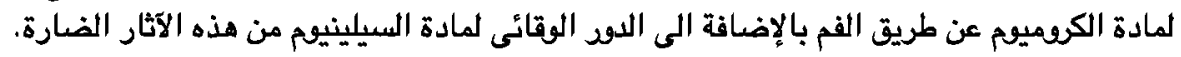

طرق وادوات البحث: تم تقسيم سته وثلاثون من ذكود الفئران اليضاء البالغة الى أربعة مجموعات متساوية حيث تشمل كل مجموعة تسعة

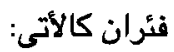

- المجموعة الأولى (الضابطه):لم تتلقى اى علاج وتتفذى على نظام غذائ منتظم بالإضعافة الى الماء.

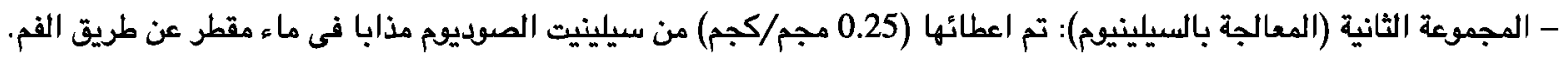

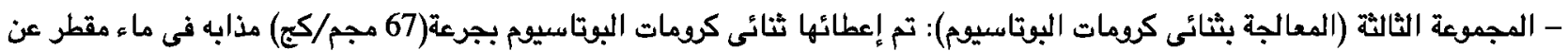
طريق الفم. - المجموعة الرابعة: (المعالجة بثنائى كرومات البوتاسيوم وسيلينيت الصوديوم معا): بنفس الجرعات التى ذكرت كما هو الحال فى المجموعتان الثانية والثالثة.

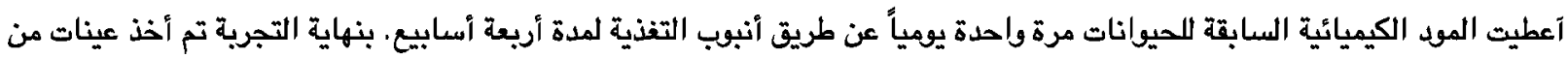

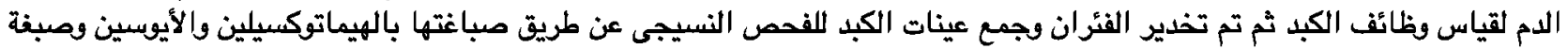

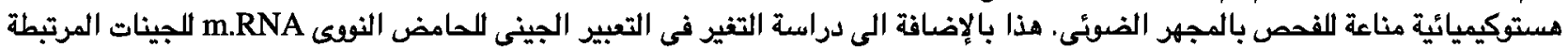
بتفاعلات الاكسدة عن طريق تفاعل البلمرة المتسلسل الحقيقئ.

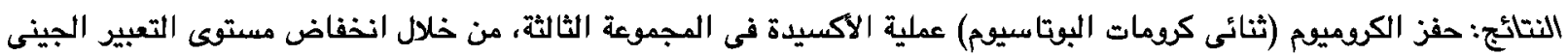

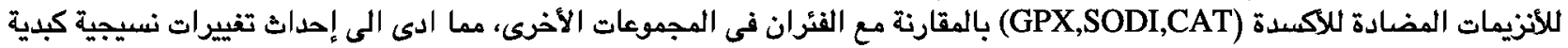

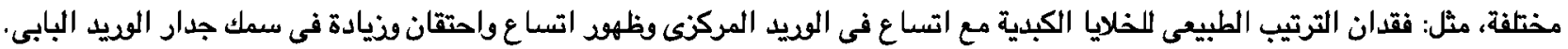

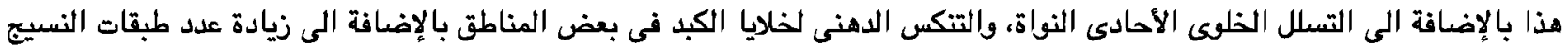

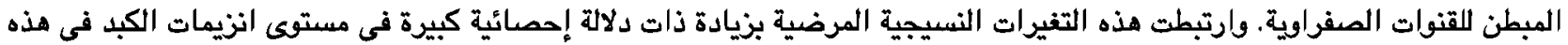
المجموعة بالمقارنة مع المجموعات الأخرىى.

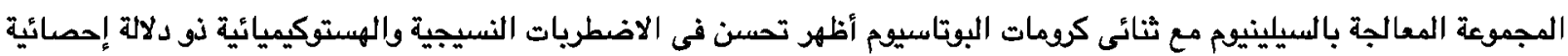

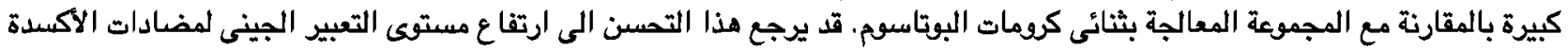

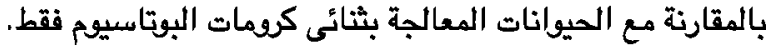

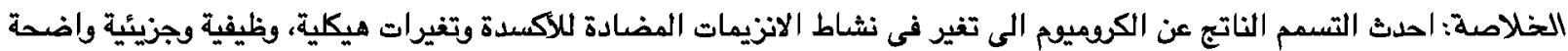

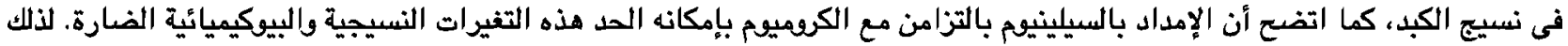

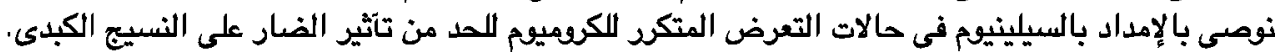

